\title{
ANALISA EFEKTIFITAS PENERAPAN MEDIA PEMBELAJARAN BERBASIS SMARTPHONE PADA PENINGKATAN HASIL BELAJAR BIOLOGI
}

\author{
Haning Hasbiyati \\ Program Studi Pendidikan Biologi Universitas Islam Jember \\ email: haninghasbiyati@gmail.com
}

\begin{abstract}
ABSTRAK: Tujuan penelitian ini adalah untuk menganalisa efektifitas penerapan media pembelajaran berbasis smartphone pada peningkatan hasil belajar biologi. Metode penelitian yang digunakan adalah menggunakan metode penelitian tindakan kelas dan analisa data deskriptif kuantitatif. Penelitian tindakan kelas ini dilaksanakan dalam 2 siklus. Pembelajaran dalam penelitian ini dikatakan berhasil apabila hasil belajar siswa pada siklus I dan siklus II mencapai $70 \%$ dari ketuntasan klasikal sebesar 70. Berdasarkan hasil observasi dan tes hasil belajar diperoleh bahwa penerapan media pembelajaran berbasis smartphone pada pembelajaran Biologi efektif meningkatkan hasil belajar siswa yaitu peningkatan hasil belajar pada subjek A sebesar 22,22\% dan subyek B sebesar 5,55\%.
\end{abstract}

Kata Kunci: Efektifitas, Media Smartphone, Hasil Belajar

ABSTRACT: The purpose of this study was to analyze the effectiveness of the application of smartphone-based learning media on improving biology learning outcomes. The research method used is to use class action research methods and quantitative descriptive data analysis. This class action research was carried out in 2 cycles. Learning in this study is said to be successful if student learning outcomes in cycle I and cycle II reached $70 \%$ of class completeness of 70. Based on observations and learning outcomes tests, it was found that the application of smartphone-based learning media in Biology learning effectively improved student learning outcomes, namely increased results learning on subject $A$ was $22.22 \%$ and subject B was $5.55 \%$.

Keywords: the effectiveness, smartphone-based learning media, results learning

\section{PENDAHULUAN}

Smartphone merupakan telepon cerdas yang memiliki kelebihan dibanding alat komunikasi lainnya. Kelebihannya ditunjukkan dengan memiliki kemampuaan seperti komputer. Perkembangan smartphone dunia sangat pesat. Saat ini ada sekitar 41,3 juta pengguna smartphone dan 6 juta pengguna tablet di Indonesia, berdasarkan hasil penelitian oleh Gifary dan Kurnia dalam (Hasbiyati,
2017) tanggapan responden terhadap intensitas penggunaan smartphone mencapai nilai 69\%. Hal ini menunjukan bahwa intensitas penggunaan smartphone termasuk dalam kategori tinggi. Pemanfaatan smartphone sebagai media pembelajaran menjadi alternatif yang dapat diterapkan pada pembelajaran bagi para guru. hal ini sesuai dengan hasil penelitian bahwa E-Book berekstensi epub pada materi 
pertumbuhan dan perkembangan dapat ditampilkan di HP Android dengan baik dan layak dijadikan sebagai media pendukung pembelajaran bagi siswa pada pembelajaran IPA Biologi (Hasbiyati \& Khusnah, 2016)

Pada saat pembelajaran biologi berlangsung, siswa seringkali terlihat jenuh dan bosan. Hal ini merupakan salah satu tanda bahwa siswa kurang berminat terhadap pembelajaran IPA. Kurangnya minat siswa dalam pembelajaran ini di sebabkan siswa belum biasa mengerti makna dan fungsi dari materi yang sedang di pelajarinya dalam kehidupan sehari hari. Dari keterangan guru IPA yang mengajar di kelas VII dan VIII dapat informasi bahwa prestasi atau hasil belajar IPA siswa MTs Al - Ishlah Mayang masih kurang. nilai siswa masih banyak yang belum mencapai $\mathrm{KKM}$, terutama pada saat ujian akhir sekolah maupun ujian pertengahan semester dan pada saat pemberian tugas harian. hal ini senada dengan (Firda, 2019) bahwa berdasarkan hasil studi ini bisa disimpulkan bahwa siswa di kelas XI IPA SMA mengalami kesulitan belajar pada pembelajaran Biologi termasuk dalam kriteria tinggi. Dengan mencoba menggunakan smartphone sebagai media pembelajaran, sebagai bentuk usaha dalam meningkatkan hasil belajar pembelajaran Biologi. Penggunaan smartphone selain sebagai media pembelajaran di sekolah, juga dapat dijadikan media pembelajaran di rumah. apalagi waktu belajar di rumah lebih banyak dibandingkan di sekolah. Berdasarkan hasil penelitian bahwa terdapat hubungan yang postif dengan kategori sedang antara waktu belajar dan minat belajar terhadap prestasi belajar biologi siswa di kelas VIII SMP Da'wah Pekanbaru T.A 2017/2018 (Sari \& Oktaviani, 2018) maka sangat penting untuk menjadikan smartphone sebagai media pembelajaran. tetapi apakah ini akan benar-benar efektif sebagai media pembelajaran, maka perlu dilakukan analisa efektifitas penerapan media pembelajaran berbasis smartphone pada peningkatan hasil belajar biologi.

\section{METODE}

Metode penelitian yang digunakan adalah menggunakan metode penelitian tindakan kelas dan analisa data deskriptif kuantitatif. Penelitian tindakan kelas ini dilaksanakan dalam 2 siklus. Untuk mendapatkan hasil analisa efektifitas penerapan media pembelajaran berbasis smartphone pada peningkatan hasil belajar biologi.

Subyek pada penelitian ini adalah siswa kelas VII dan kelas VIII di MTs Al-Islah Mayang-Jember. Dengan rancangan penelitian ini sebagai berikut

Gambar 1. Rancangan Penelitian

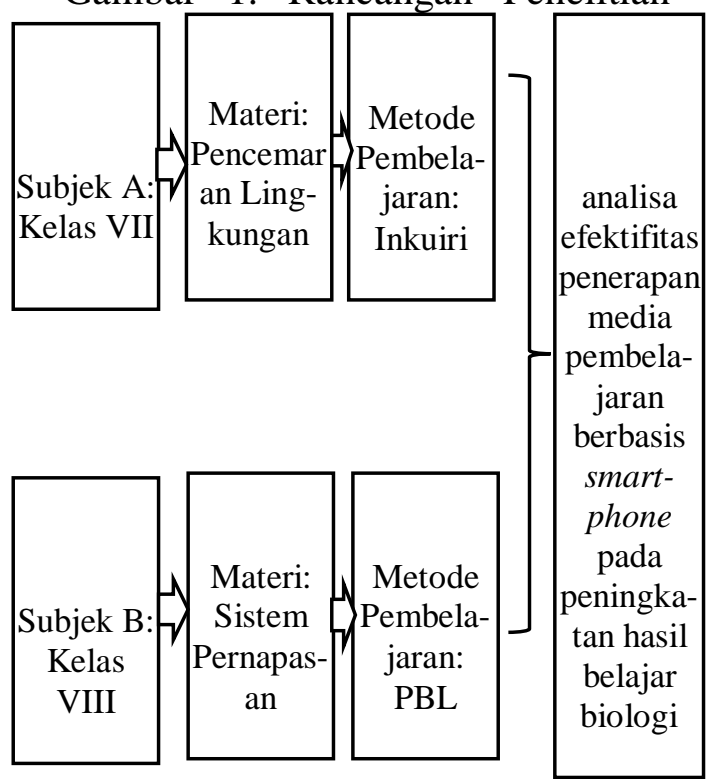

Pembelajaran dalam penelitian ini dikatakan berhasil apabila hasil belajar siswa pada siklus I dan siklus II mencapai $70 \%$ dari ketuntasan klasikal sebesar 70. dengan instrumen peneltian adalah tes hasil belajar yang diperoleh dari penerapan media pembelajaran 
berbasis smartphone pada pembelajaran Biologi dan lembar observasi. Adapun dalam penelitian ini, observasi langsung digunakan untuk mengamati secara langsung pembelajaran Biologi menggunakan media pembelajaran berbasis smartphone.

\section{HASIL DAN PEMBAHASAN}

Kegiatan penerapan media pembelajaran berbasis smartphone pada pembelajaran biologi diawali dengan tahapan perencanaan. Pada siklus 1 kegiatan yang dilakukan dalam tahap perencanaan adalah menyiapkan perangkat pembelajaran beserta media pembelajaran yang sesuai dengan langkah-langkah pembelajaran yang telah dirancang. Kemudian pada siklus 2 diadakan perencanaan ulang yang meliputi hasil refleksi dari siklus I. Proses pembuatan media berbasis smartphone digunakan dengan offline dan online. Jika dibuat online $100 \%$ dikhawatirkan akan ada kendala saat proses pembelajaran. Hal ini sesuai dengan hasil penelitian (Azmi, Joebagio, \& Suryani, 2016) pengembangan aplikasi semi-online dapat menjadi solusi dalam upaya untuk membuat menarik minat siswa dalam menggunakan aplikasi dan tidak mendapatkan gangguaan selama proses pembelajaran berlangsung. Maka pada media ini mengkombinasikan foto dan video yang relevan dengan materi dan metode pembelajaran.

Tahap selanjutnya adalah pelaksanaan dari penerapan media pembelajaran berbasis smartphone pada pembelajaran Biologi. Berdasarkan hasil observasi pada kegiatan pelaksanaan pembelajaran diperoleh data sebagai berikut:

Tabel 1. Hasil observasi

\begin{tabular}{|c|c|c|}
\hline & SUBJEK A & SUBJEK B \\
\hline & 1. Pada saat & 1. Sebagian besar \\
\hline & melihat tayangan & siswa terlihat \\
\hline & video pada & antusias \\
\hline & smartphone, & saat pembelajaran \\
\hline & sebagian siswa & menggunakan \\
\hline & ada yang tidak & smartphone \\
\hline & fokus dengan & 2. Siswa terlihat \\
\hline & video dan & mudah memahami \\
\hline & bergurau dengan & pelajaran yang \\
\hline & kelompok lain, & diberikan \\
\hline & 2. Pada saat & guru, hal ini \\
\hline & presentasi siswa & dilihat dari \\
\hline & cenderung masih & meraka \\
\hline & pasif dan hanya & mudah \\
\hline & terpaku pada & menyelesaikan \\
\hline & buku, & masalah saat \\
\hline $\mathbf{S}$ & 3. Ada & berdiskusi di kelas \\
\hline & sebagian siswa & 3. Siswa lebih \\
\hline $\mathbf{I}$ & $\begin{array}{l}\text { yang masih pasif } \\
\text { dalam }\end{array}$ & $\begin{array}{l}\text { mudah belajar } \\
\text { dengan }\end{array}$ \\
\hline $\mathbf{K}$ & berdiskusi, hal & menggunakan \\
\hline & itu mungkin & smartphone dan \\
\hline $\mathbf{L}$ & disebabkan & lebih mudah pula \\
\hline & karena saat & menganalisis \\
\hline $\mathbf{U}$ & $\begin{array}{l}\text { berada dalam } \\
\text { sebuah }\end{array}$ & $\begin{array}{l}\text { masalah yang ada } \\
\text { pada video vang }\end{array}$ \\
\hline $\mathbf{S}$ & kelompok siswa & diberikan oleh \\
\hline & merasa malu dan & guru. \\
\hline & takut salah & 4. Adapula siswa \\
\hline & dengan apa yang & yang pasif pada \\
\hline 1 & akan dilontarkan & saat pembelajaran, \\
\hline & & kelompok terdapat \\
\hline & & siswa lain yang \\
\hline & & malu sesama \\
\hline & & teman yang lain. \\
\hline & & Secara \\
\hline & & keseluruhan \\
\hline & & pengamatan \\
\hline & & penelti terlihat \\
\hline & & sebagian \\
\hline & & siswa sudah \\
\hline & & cukup aktif dan \\
\hline & & antusias dalam \\
\hline & & proses \\
\hline & & pembelajaran, \\
\hline
\end{tabular}


siswa sudah bias

saling bertukar

pendapat,

berdiskusi,

bekerjasama dan

menerima

pendapat orang

lain.

\begin{tabular}{|c|c|c|}
\hline & 1. siswa terlihat & 1. Sebgain besar \\
\hline & lebih mudah & siswa terlihat \\
\hline & untuk & antusias \\
\hline & mengerjakan & saat pembelajaran \\
\hline & tugas dalam & menggunakan \\
\hline & kelompok & smartphone \\
\hline & 2. siswa & 2. Siswa terlihat \\
\hline $\mathbf{S}$ & jauh & mudah memahami \\
\hline & berani untuk & pelajaran yang \\
\hline I & berbicara dalam & diberikan \\
\hline & mengungkapkan & guru, \\
\hline K & pendapatnya & hal ini dilihat dari \\
\hline & ketika & meraka yang \\
\hline $\mathbf{L}$ & berdiskusi. & mudah memahami \\
\hline & 3. Ketika & materi yang ada di \\
\hline $\mathbf{U}$ & melaksanakan & video dan mampu \\
\hline & kegiatan & menyelesaikan \\
\hline $\mathbf{S}$ & praktikum siswa & masalah saat \\
\hline & terlihat lebih & berdiskusi di kelas \\
\hline & kompak sesama & 3. siswa sudah \\
\hline 2 & teman dalam & bisa \\
\hline & kelompoknya. & saling bertukar \\
\hline & & $\begin{array}{l}\text { pendapat, } \\
\text { berdiskusi , }\end{array}$ \\
\hline & & bekerjasama dan \\
\hline & & menerima \\
\hline & & $\begin{array}{l}\text { pendapat } \\
\text { orang lain. }\end{array}$ \\
\hline
\end{tabular}

Maka berdasarkan hasil observasi diperoleh kesimpulan sebagai berikut bahwa penerapan media pembelajaran berbasis smartphone pada pembelajaran Biologi dapat dilaksanakan dengan baik dan lancar. Siswa lebih aktif dan bersemangat dalam proses pembelajaran dengan menggunakan media tersebut. Siswa juga lebih aktif dalam memahami materi baik membaca, bertanya maupun mengamati gambar dan video pada smartphone yang disajikan pada siswa. Dengan begitu dapat disimpulkan bahwa ada respon positif siswa terhadap penerapan media pembelajaran berbasis smartphone pada pembelajaran Biologi yang ditunjukkan dari aktivitas positif dari siswa subjek A dan subjek B. Hal ini sesuai dengan hasil penelitian (Sucahyono, 2016) diperoleh pada penelitian efesiensi penerapan media ajar berbasis digital class sebagai penunjang pembelajaran pada SMPN 4 Pamekasan, dapat disimpulkan adanya respon siswa dalam pembelajaran dengan menunjukkan respon yang positif, hal ini dibuktikan dengan aktivitas siswa yang mengalami peningkatan pada setiap pembelajarannya.

Pada tahap pengambilan data untuk mengetahui hasil belajar dari penerapan media pembelajaran berbasis smartphone pada peningkatan hasil belajar biologi diperoleh hasil sebagai berikut.

Gambar 2. Grafik Persentase ketuntasan hasil belajar siswa

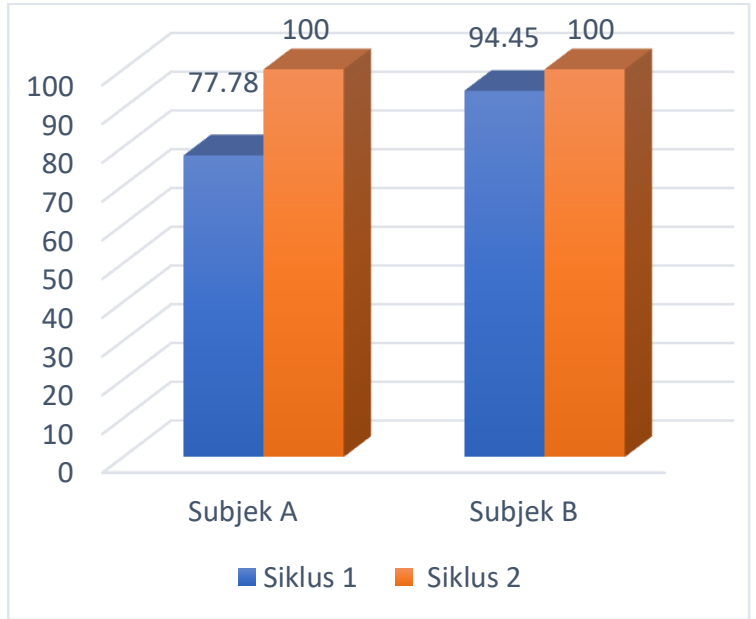


Dari grafik persentase ketuntasan hasil belajar siswa diperoleh pada subjek A ketuntasan hasil belajar siswa siklus 1 sebesar $77,78 \%$ dan pada siklus 2 sebesar $100 \%$. Sedangkan pada subjek B ketuntasan hasil belajar siswa siklus 1 sebesar $94,45 \%$ dan pada siklus 2 sebesar $100 \%$. Sehingga penerapan media pembelajaran berbasis smartphone pada pembelajaran Biologi mengalami peningkatan hasil belajar pada subjek A sebesar 22,22 \% dan subjek B sebesar 5,55\%.

Berdasarkan hasil observasi dan tes hasil belajar diperoleh bahwa penerapan media pembelajaran berbasis smartphone pada pembelajaran Biologi efektif meningkatkan hasil belajar siswa.

\section{KESIMPULAN}

Berdasarkan kegiatan analisa efektifitas penerapan media pembelajaran berbasis smartphone pada peningkatan hasil belajar biologi melalui kegiatan observasi dan tes hasil belajar, maka diperoleh kesimpulan bahwa dengan penerapan media pembelajaran berbasis smartphone efektif pada peningkatan hasil belajar biologi.

\section{DAFTAR PUSTAKA}

E-Book Berekstensi Epub Sebagai Media Pembelajaran. (2017). Jember. Kyai Mojo.

Analisa Efesiensi Penerapan Media Ajar Berbasis Digital Class Pada SMPN 4 Pamekasan. (2016). Jurnal Insand Comtech. Vol. 1, No. 1.

Analisis Kesulitan Belajar Siswa Sma Pada Materi Kultur. (2019).
Jurnal Bio-Lectura: Jurnal Pendidikan Biologi. Vol 6, No 1.

Hubungan Antara Waktu Belajar Dan Minat Belajar Terhadap Prestasi Belajar Biologi Siswa Di Kelas VIII Smp Da'wah Pekanbaru T.A 2017/2018. (2018). Bio-Lectura: Jurnal Pendidikan Biologi. Vol 05, No 02.

Pengembangan e-Book Berekstensi epub Pada Pembelajaran IPA SMP. (2016). Jurnal Bioshell. Vol 04, No 01.

Studi Pendahuluan Pengembangan Aplikasi Smartphone Sebagai Alternatif Media Pembelajaran Sejarah. (2016). Jurnal Vidya Karya. Volume 31, Nomor 1. 